while constantly stirring, bring sauce to a boil. Reduce heat to low. Cover saucepan and let it simmer for 30 to 40 minutes, being careful not to burn the bottom.

Depending upon the quality of the tomato paste used, it may need more water or wine for the desired thickness. Before serving, strain sauce. Discard bay leaf, onions, and celery. Correct seasonings with the addition of some more salt or sugar. Serve with chicken.

The Bakery Restaurant, Chicago

Louis Szathmary (CheF Louis)

\title{
ARTHUR LUNDKVIST'S SWEDISH ODE TO WHITMAN
}

Writing in the late 1940s about Whitman's influence in Sweden, Frederik Schyberg noted that his impact was first felt "among the Swedish lyricists and prose writers of the so-called 'cult of life' group," especially in the early work of Arthur Lundkvist. ${ }^{1}$ Schyberg went on to refer to one particular poem in Lundkvist's 1929 collection, Naket Liv [Naked Life], "a poem addressed to Whitman which in poetic conciseness and originality can only be compared to Garcia Lorca's famous ode to Whitman." (It is fitting that it would be Lundkvist who would, just after the Second World War, translate Lorca's ode into Swedish.) Schyberg pointed out that Lundkvist continued to write "in the Whitmanesque vein" and became an important critic as well as one of Sweden's most distinguished poets; his critical essays on American writers, including Whitman, have served to introduce generations of Swedish readers to American literature. Schyberg concluded by noting that Lundkvist's work "deserves to be recognized and appreciated outside Scandinavia."

Lundkvist's work has by now certainly gained recognition outside of Scandinavia - it has been translated into French, Spanish, Russian, German, Italian, and many eastern European languages - but it has never received much attention in English-speaking countries. Stephen P. Sondrup, who has worked on one of the few substantial English translations of Lundkvist's poetry, notes that by 1955, the centennial of Leaves of Grass, virtually nothing of Lundkvist's was available in English (even though just a year earlier, in 1954, Lundkvist had published a new book of poems with the Whitmanian title Liv som gras [Life as Grass]), and even today "relatively little of Lundkvist's enormous oeuvre has been presented to the Englishspeaking world." ${ }^{3}$

Born in 1906, Lundkvist remains to this day an active force in Swedish literature, a member of the Swedish Academy since 1968 and a controversial and outspoken participant in recent Nobel Prize decisions. Like Whitman, Lundkvist came from a humble farm family and had little formal education; he was a voracious reader, but has always felt isolated from academic life and academic writers. He was involved with an active group of young Swedish proletarian writers in the 1920s and 1930s, but was never a doctrinaire socialist writer, developing instead a quite individualistic and unpredictable view of the role of the artist. As was the case with Whitman, Lundkvist often found himself surrounded by revolutionary thinkers and social idealists, but, again like Whitman, he has always managed to go beyond dogmatists of all kinds, grounding himself more in experience than in theory. His description of his artistic stance sounds as if it is echoing Whitman: 
My childhood landscape, the world outdoors there, I carried with me as an experience. I did not forget the poverty and the privations, but put them into a larger context. A kind of socialism was constantly in my mind, but I turned away from party pews, dogmatism, treacherous illusions of different types. No, I don't think I have betrayed, rather I have liberated myself from a series of limitations and prejudices. ${ }^{4}$

Lundkvist's poem to Whitman, the one Schyberg compares favorably to Lorca's ode, has to my knowledge never appeared in an English translation. ${ }^{5}$ The following translation was done while I was visiting Göteborgs Universitet in Göteborg, Sweden, during the spring of 1985. Mark Troy, Jeffrey Miller, and Linda Sckenck of the faculty of Göteborg's Engelska institutionen all worked on the translation. In the poem, Lundkvist captures his admiration for the Whitman who-like Lundkvist himself-fondly recalls his youthful days of easy camaraderie when he was immersed in instinctual life, his footprints sunk deep in the ground, his life opened to the elements of nature, drenched in reality, turning his experience into glowing illumination through song. The celebration of the vital instinctual life in this poem remains a constant in all of Lundkvist's work.

\section{WHITMAN}

You, brother of all, you, man with a great heart, you, strong wanderer in the storm of life.

You never forgot these mornings from your youth when you were with the comrades in a boat on the sea and fished: the scent of kelp, the feeling over the water shouts between the boats and blue smoke-plumes from the small fishing boats$\mathrm{O}$, this strong beautiful camaraderie between men!

You, lover of life, for you the days were like cool green waves: purposeful, joy-filled you let them wash over you, uplift you, heave you, cast you forward-

Early morning wanderer, you walked through the world in a great unbuttoned cape after you there came a whirling wind;

you sang and your song still lingers between the heights, echoes over the oceans; your footprints stand deep, indelible in the earth, showing The Way, and light blossoms out of them. 


\section{NOTES}

1 Schyberg, Walt Whitman, trans. Evie Allison Allen (New York: Columbia University Press, 1951), p. 313.

2 Schyberg, p. 314.

3 See Sondrup's preface to Lundkvist's The Talking Tree (Provo, Utah: Brigham Young University Press, 1983), p. xiii. This collection makes available translations of Lundkvist's prose poems written during the 1960s and 1970s; it contains a useful introduction by Diana W. Wormuth (pp. 1-35), who translated the poems in collaboration with Sondrup.

4 Quoted in Talking Tree, p. 17.

5 The original poem appeared in Naket Liv (Stockholm: Albert Bonniers Forlag, 1929), pp. 64-65. 